\title{
INDUCED SINKHOLE FORMATION ASSOCIATED WITH INSTALLATION OF A HIGH-PRESSURE NATURAL GAS PIPELINE, WEST-CENTRAL FLORIDA
}

\author{
Ted J. Smith, P.G., C.P.G. \\ Earth \& Water Resources, LLC, 2000 S. Florida Ave., Lakeland, Florida, 33803 USA, tjsmith@earth-waterllc.com \\ George C. Sinn, Jr., P.E. \\ Central Florida Testing Laboratories, Inc., 12625 40 Sth St., Clearwater, Florida, 33762 USA, gsinn@cftlinc.com
}

\begin{abstract}
Induced sinkholes are a known geologic hazard and may be associated with construction activities that cause alteration of ground water flow patterns or induce rapid loads and/or vibrations on karst-affected soils and rocks. This study describes the geophysical and geotechnical investigation of a site in northern Hillsborough County, Florida, where a large diameter underground high-pressure natural gas pipeline was installed utilizing horizontal directional drilling (HDD) methods. Objectives of the investigation were to evaluate the impacts of: 1) pipeline installation on existing ground-collapse features, 2) potential induced ground subsidence and 3) possible effects on water bodies and building structures. The site was investigated utilizing geophysical testing (electrical resistivity), standard penetration test (SPT) borings, and ground vibration monitoring during pipeline construction. In the investigation, subsurface conditions indicative of possible preexisting weakened soil and rock materials associated with incipient raveled zones in overburden soils and soil-filled conduits in limestone bedrock were found in proximity to the pipeline corridor. During the HDD boring and pipeline installation, noticeable ground vibrations occurred, along with formation of several ground settlement/collapse features. The data suggest two mechanisms of induced sinkhole formation: erosion of weak zones in overburden soils by the high pressure drilling mud and/or erosion of weak, soil-filled conduits in limestone bedrock. In addition to current settlement impacts to the property, the investigation found a potential for future ground subsidence associated with undetected eroded and raveled zones that may in the future propagate to the land surface.
\end{abstract}

\section{Introduction}

Induced sinkholes are caused or accelerated by human activities and are associated with two broad conditions: those triggered by water level declines, typically from ground water withdrawals (pumping), or those related to construction activities (Newton, 1987). In west-central Florida, sinkhole formation and ground subsidence accompanying heavy ground water pumping are common occurrences and are typically associated with rapid declines in the potentiometric surface of the Floridan aquifer. This causes an increase in effective stress over pre-existing zones of weakness, such as soil or rock voids formed by dissolution. Increased pumping can alter the flow regime in the aquifer, increasing flow rates within conduits causing loosening of soil plugs in partiallyfilled cavities in the limestone bedrock and triggering downward raveling of overburden soils. Pumping can induce recharge from the surficial aquifer, destabilizing incipient raveled soil zones in the subsurface.

Sinkhole formation can also be triggered by construction activities such as water impoundment in reservoirs and retention basins, ground loading, ground vibrations from heavy equipment, changes to natural drainage patterns by diversion of stormwater, and drilling of borings and water wells. The mechanisms activating sinkhole formation would include increased ground water recharge and flow to weakened soil zones and bedrock conduits, and abrupt increases in loads and/or vibrations on pre-existing zones of weakened soils and rocks associated with incipient sinkhole conditions.

This paper presents a case history of a geophysical and geotechnical investigation conducted at a site in northern Hillsborough County, Florida. The purpose of the investigation was to evaluate impacts from installation of an underground, 0.9-meter (36-inch) diameter, high-pressure natural gas pipeline across the property. Investigation objectives included evaluation of existing karst subsidence feature(s), potential for induced ground subsidence, and impacts on building structures 
and water bodies near the property. The study methods included an electrical resistivity survey of the pipeline corridor, subsurface testing by standard penetration test (SPT) borings, and ground vibration monitoring during pipeline installation.

\section{Location and Geologic Setting}

The site is located in extreme north-central Hillsborough County, Florida (Figure 1). The subject property is approximately 20 acres in size and is bordered by Hog Island Lake on the southern and eastern sides and vegetated wetland areas on the northern side. The site is generally flat with minimal topographic relief, with ground elevations ranging from approximately 22 meters (71 ft. NGVD) in northwestern portions of the property to 20 meters (64 ft. NGVD) along Hog Island Lake to the south and east, and the fringing wetland areas on the north side. Two large residential structures and associated outbuildings are currently located on the property (Figure 2).

\section{Geology}

The subject property lies within the Land O' Lakes Karst Plain (Scott, 2005), which encompasses much of northwestern Hillsborough County, as well as coastal areas of Pinellas, Pasco, and Hernando Counties. The geomorphic province is formed by a series of Pleistocene age marine terraces developed on sandy and

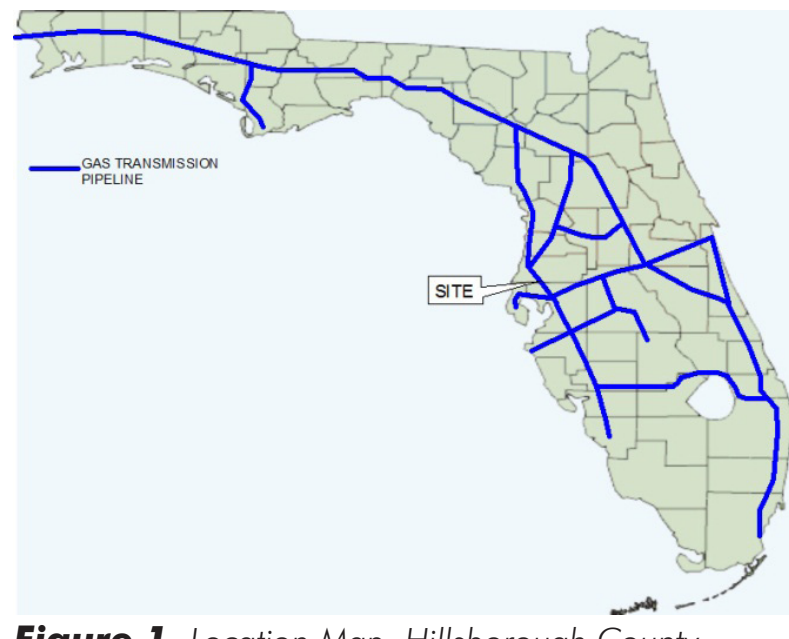

Figure 1. Location Map, Hillsborough County, Florida.

clayey sediments and carbonate rocks of the Miocene age Hawthorn Group and the Oligocene Suwannee Limestone. The project site is located within the Penholoway terrace (Healy, 1975), which formed during retreating sea levels at elevations between 13 and 21 meters ( 42 and $70 \mathrm{ft}$.). This terrace has been modified by fluvial and marine erosion, stream and lake deposition, and eolian deposits and further shaped by karst-related landforms including sinkhole lakes, cypress domes, and broad wetland basins. Numerous lakes and swamps are present within and near the project area. These features were created by karst processes resulting in broad

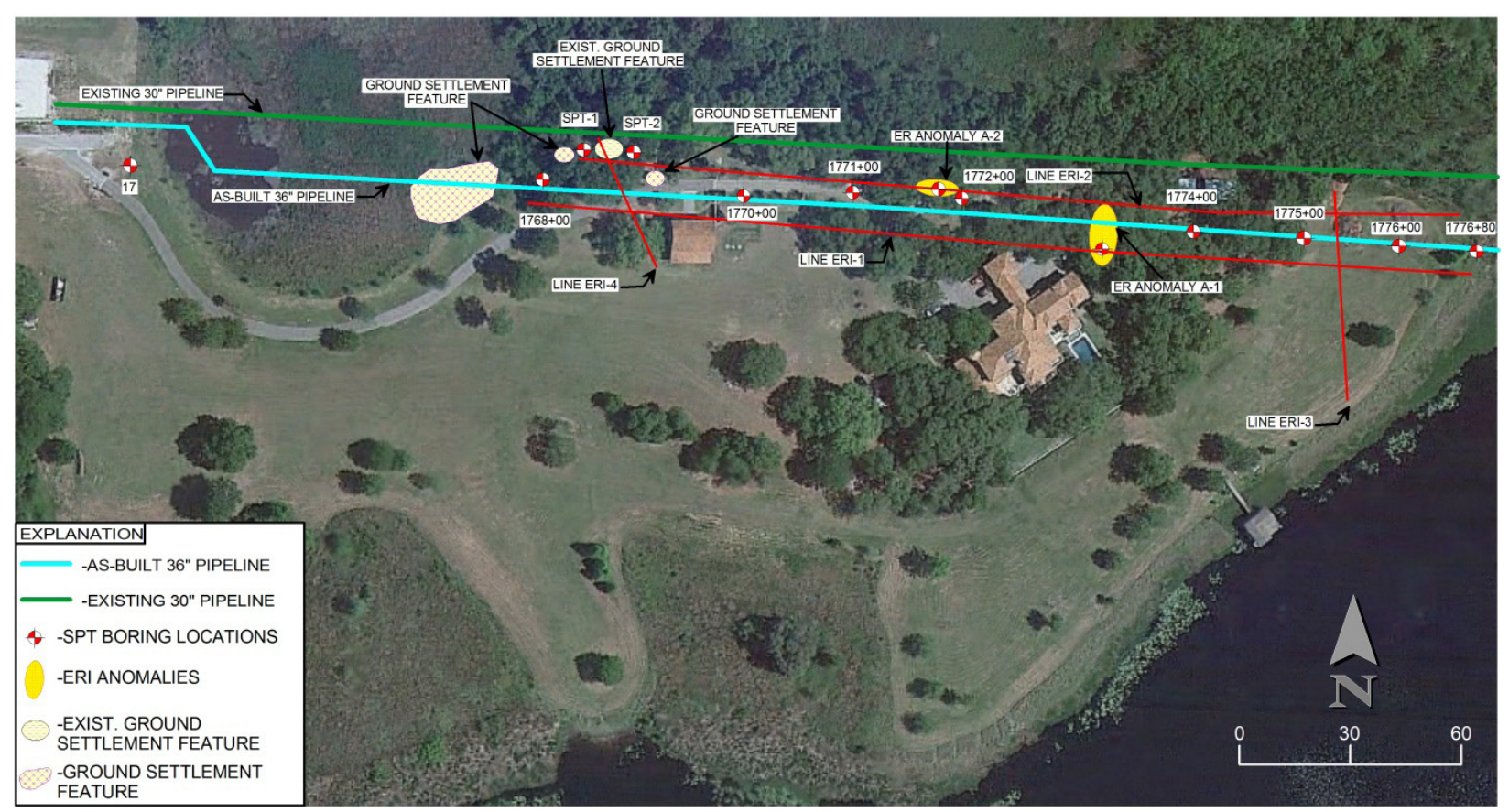

Figure 2. Geophysical Testing and Boring Location Plan showing pipeline easement, building structures, and testing locations. 
wetland basins and lakes formed by multiple coalescing sinkhole and subsidence features.

Peninsular Florida is underlain by a thick sequence of Paleogene carbonate rocks that form the Florida platform, which is capped by a thin series of Miocene to Holocene age carbonate rocks and siliciclastic sediments. Important geologic and hydrogeologic units in north-central Hillsborough County are summarized in Table 1. Descriptions of each unit are taken from Arthur et al. (2008), Campbell (1984), and Scott, (1988).

\section{Hydrogeology}

Two principal hydrogeologic units are present in the project area (Table 1), the surficial aquifer system and the Upper Floridan aquifer system. The surficial aquifer is hosted primarily by permeable sandy soils within undifferentiated surficial deposits. Clayey soil units within the upper Hawthorn Group, where present, form a confining unit separating the surficial aquifer from the Upper Floridan aquifer, which is hosted primarily in the Suwannee Limestone and deeper limestone formations (Ocala Limestone and Avon Park Formation).

The surficial aquifer is generally unconfined with the potentiometric surface corresponding with the water table, which occurs at depths of less than 1.5 meters ( 5 ft.) in the project area. The potentiometric surface of the Upper Floridan Aquifer system in the area occurs at elevations of 18 to 20 meters (60 to $65 \mathrm{ft}$. NGVD). While the Upper Floridan Aquifer is typically confined by low permeability sediments of the Hawthorn group, hydraulic connection with the surficial aquifer often occurs in local areas where the confining units have been removed by erosion or are breached by sinkhole features filled with permeable sandy sediments. Lakes and wetland basins are common sites of paleo or relic sinkhole activity and provide for hydraulic connection between the surficial and Floridan aquifers.

\section{Karst and Sinkhole Development}

In west-central Florida sinkhole formation occurs by two primary mechanisms: cover-collapse and coversubsidence (Sinclair et al., 1985). Buried paleo-sinkholes or paleo-karst structures include ancient sinkhole features that have been buried or filled with younger soils or sediments. They also constitute a geologic hazard since they are subject to reactivation by raveling and further subsidence. The stability of paleo-karst structures varies greatly depending on the degree of consolidation of infilling sediments, the physical connection with cavities and conduits in the limestone formation, and the hydraulic connection with the deeper aquifers. Lakes and wetland basins are commonly related to paleo-sinkhole activity and may serve as recharge areas to the Floridan Aquifer. Paleo-karst structures are extremely common features in the subsurface in west-central Florida (Horwitz and Smith, 2003; Wilson and Shock, 1996).

\section{Pipeline Construction}

The gas pipeline consisted of a nominal 0.9-meter diameter (36-inch) steel pipe installed through a horizontal directional borehole located within an easement traversing the northern side of the subject property. The easement is approximately 15 meters wide and 437 meters long (50 by 1,435 ft.) with a general west to east alignment extending from the northwest corner of the site to the eastern property boundary along Hog Island Lake. The easement passes in close proximity to the main residential building and outbuildings (Figure 2). The borehole for the pipeline was completed using horizontal directional drilling (HDD) methods to depths

Table 1. Regional Geologic and Hydrogeologic Units, Northern Hillsborough County.

\begin{tabular}{|c|c|c|c|c|}
\hline System & Series & $\begin{array}{l}\text { Lithostratigraphic } \\
\text { Unit }\end{array}$ & Lithology & $\begin{array}{l}\text { Hydrostratigraphic } \\
\text { Unit }\end{array}$ \\
\hline \multirow[b]{2}{*}{ Quaternary } & Holocene & \multirow{2}{*}{$\begin{array}{l}\text { Undifferentiated } \\
\text { Sands and Clays }\end{array}$} & \multirow{2}{*}{$\begin{array}{l}\text { Very fine to medium grained quartz sand, } \\
\text { minor silty, clayey and organic soils, local } \\
\text { deeper clayey soils and shell beds }\end{array}$} & \multirow[b]{2}{*}{ Surficial Aquifer System } \\
\hline & Pleistocene & & & \\
\hline \multirow[t]{2}{*}{ Tertiary } & Miocene & $\begin{array}{l}\text { Tampa Member: } \\
\text { Arcadia Formation } \\
\text { (Hawthorn Group) }\end{array}$ & $\begin{array}{l}\text { White to tan, quartz sandy, locally clayey, } \\
\text { fossiliferous limestone and dolostone, } \\
\text { phosphatic, clayey, locally silicified in up- } \\
\text { per portion }\end{array}$ & \multirow[t]{2}{*}{ Upper Floridan Aquifer } \\
\hline & Oligocene & Suwannee Limestone & $\begin{array}{l}\text { Pale yellow white, sandy, fossiliferous, fine } \\
\text { grainstone }\end{array}$ & \\
\hline
\end{tabular}


up to 30 meters (100 ft.), to an approximate elevation of -11 meters ( $-35 \mathrm{ft}$. NGVD). The entry point for the HDD borehole is located near the northwest corner of the subject property, extending over a horizontal design length of approximately 1,074 meters $(3,522 \mathrm{ft}$.) to the pipeline exit point east of the site and Hog Island Lake.

In addition to the new pipeline, an existing 0.75 -meter (30-inch) diameter underground gas pipeline is located just north of the subject property and generally parallels the easement for the new pipeline. Although the construction details and depth of the older pipeline are not known, it was presumed that it was installed using similar HDD methods as with the current pipeline. One concern at the site is an existing ground collapse feature located near the existing smaller gas pipeline (Figure 2). The collapse feature is oval in shape with dimensions of approximately 6 by 9 meters (20 by $30 \mathrm{ft}$.) extending to a depth in excess of 5 meters (15 ft.). Given the location and morphology of the collapse feature, it is the authors' opinion that it is an induced sinkhole collapse associated with the installation of the existing gas pipeline.

Minimal geotechnical data were collected by the pipeline contractor, consisting of two SPT borings drilled at each end of the pipeline alignment and advanced to depths of approximately 30 meters (100 ft.).

\section{Electrical Resistivity Survey}

An electrical resistivity imaging (ERI) survey was conducted over accessible portions of the pipeline corridor and surrounding area to assist in characterizing the general subsurface geology and identify potential anomalous subsurface geological features for further investigation. The ERI survey consisted of four transect lines using up to 112 electrodes at a spacing of 3 meters (10 ft.). Two transects oriented approximately west to east were located within the pipeline corridor, with lengths of approximately 270 and 250 meters (885 ft. and $820 \mathrm{ft}$.). Additionally, two shorter transects, approximately 128 and 41 meters (420 ft. and $135 \mathrm{ft}$.) long and oriented perpendicular to the pipeline corridor, were completed in the eastern and western portions of the property. The western transect was located near the western side of the masonry outbuilding and the existing ground collapse feature. The locations of the ERI transects are shown on Figure 2.

The resistivity data were collected using a combined dipole-dipole and inverse Schlumberger electrode array, and were subjected to inverse modeling to produce two-dimensional resistivity profiles for each transect. The modeled data were then analyzed with respect to identifying anomalous electrical resistivity signatures associated with potential subsurface karst features based on the following criteria:

Columnar patterns of higher resistivity materials extending to the depth of apparent limestone bedrock. These patterns may indicate sand-filled depressions related to in-filled or paleo-sinkhole features or potential zones of soil raveling.

Patterns indicative of localized increased depth of limestone bedrock related to potential paleo-sinkhole features.

The resistivity profiles (Figure 3 ) were interpreted as showing a surficial layer of higher resistivity sandy soils overlying moderate to low resistivity materials correlated with limestone occurring at approximate depths of 11 to 14 meters (35 to $45 \mathrm{ft}$.). Two anomalous areas were identified within the central portion of the survey area located north and northwest of the main residential building. The anomalies were characterized by areas of higher resistivity materials at depth representing possible zones of downward raveling sands extending to limestone bedrock. The anomalies were subsequently tested by SPT borings A-1 and A-2.

\section{Geological Conditions}

Standard penetration test (SPT) borings were used to investigate subsurface conditions and geophysical anomalies within the pipeline corridor. The borings were conducted using conventional mud rotary drilling methods, in general accordance with ASTM Standard D 1586. Thirteen (13) SPT borings were performed along the alignment of the proposed gas pipeline and advanced to depths ranging from approximately 12 to 34 meters (40 to $110 \mathrm{ft}$.) below ground surface. The boring locations are shown on Figure 2.

The subsurface geological and geotechnical data were used to construct a geologic profile of the pipeline corridor, depicted in Figure 4. Three generalized subsurface units or soil strata were encountered in the borings: 

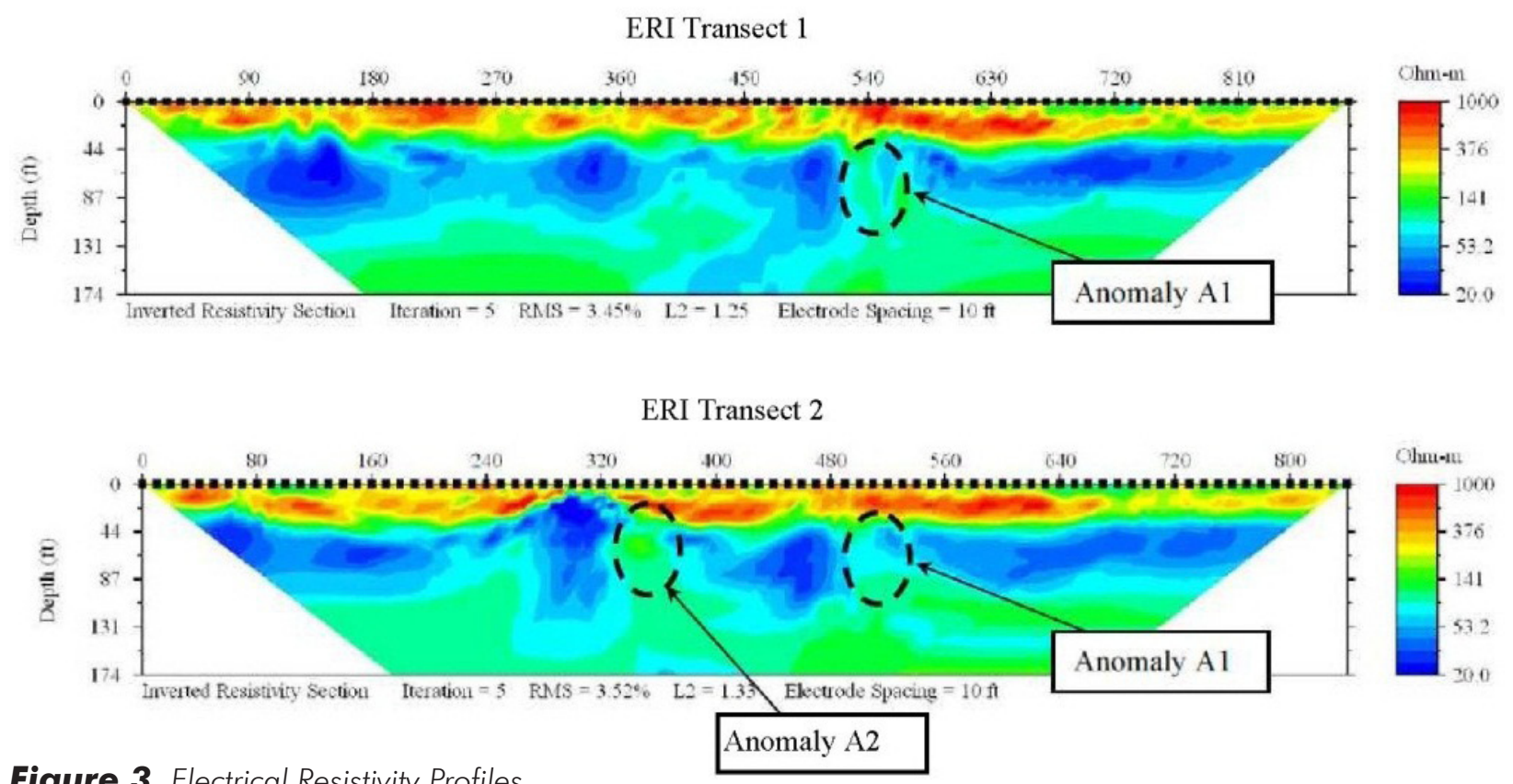

Figure 3. Electrical Resistivity Profiles.

Stratum 1 Sand, Sand with Clay, Peat USCS class. $=$ SP, SP-SC, Pt

Stratum 2 Sand with Clay, Clayey Sand, Sandy Clay

USCS class. $=$ SP-SC, $\mathrm{SC}, \mathrm{CH}$

Stratum 3 Limestone, variably weathered

Stratum 1 comprises the surficial soil unit at the site and consists of dominantly light-colored fine-grained quartz sand, with localized near surface deposits of peat (1 to $3 \mathrm{ft}$.) and deeper lenses of sand with clay and clayey sand (Stratum 2). The soil unit has a variable thickness, extending to depths ranging from approximately 7 to 14 meters ( 22 to $47 \mathrm{ft}$.) in eastern and central portions of the site to 23 meters ( $75 \mathrm{ft}$.) in a boring located near the entry point of the gas pipeline at the northwestern corner of the property. Sandy soils similar in appearance to Stratum 1 were also encountered as localized infilled zones within the limestone bedrock in the eastern portion the property.

Stratum 2 consists of variably clayey sand and minor sandy clay and was encountered as local shallow lenses within the surficial sands, as a deeper persistent soil unit extending to limestone bedrock, and as apparent in-filled zones within the limestone.
Limestone bedrock (Stratum 3) consists of light colored (white to gray) fine grained limestone, with local clay fracture fillings and soil in-filled zones. The limestone was encountered at variable depths, ranging from 10 to 19 meters (32 to $62 \mathrm{ft}$.) in eastern and central portions of the site. The limestone bedrock deepens to the west to depths in excess of 24 meters ( $80 \mathrm{ft}$.).

The subsurface soil and rock materials exhibited a variable density and consistency over the depth of the SPT borings. Isolated zones of very loose and very soft soil and rock materials over intervals of 0.5 to 2 meters (1.5 to $6.5 \mathrm{ft}$.) were encountered in several borings in the western and eastern portions of the site. The weak soils and rock zones occurred within the mid-depth overburden soils and as deeper soft and soil in-filled zones within the limestone bedrock.

During drilling, partial to complete losses of drilling fluid circulation were recorded in 6 of the 13 SPT borings. The circulation losses typically occurred in association with very loose zones within the clayey soil unit (Stratum 2) near the soil/limestone contact, within the upper portion of the limestone formation, or within soil in-filled zones within the limestone bedrock.

The surficial sands and clayey soils (Strata 1 and 2) are correlated with undifferentiated Holocene and Pleistocene deposits. The limestone bedrock correlates 

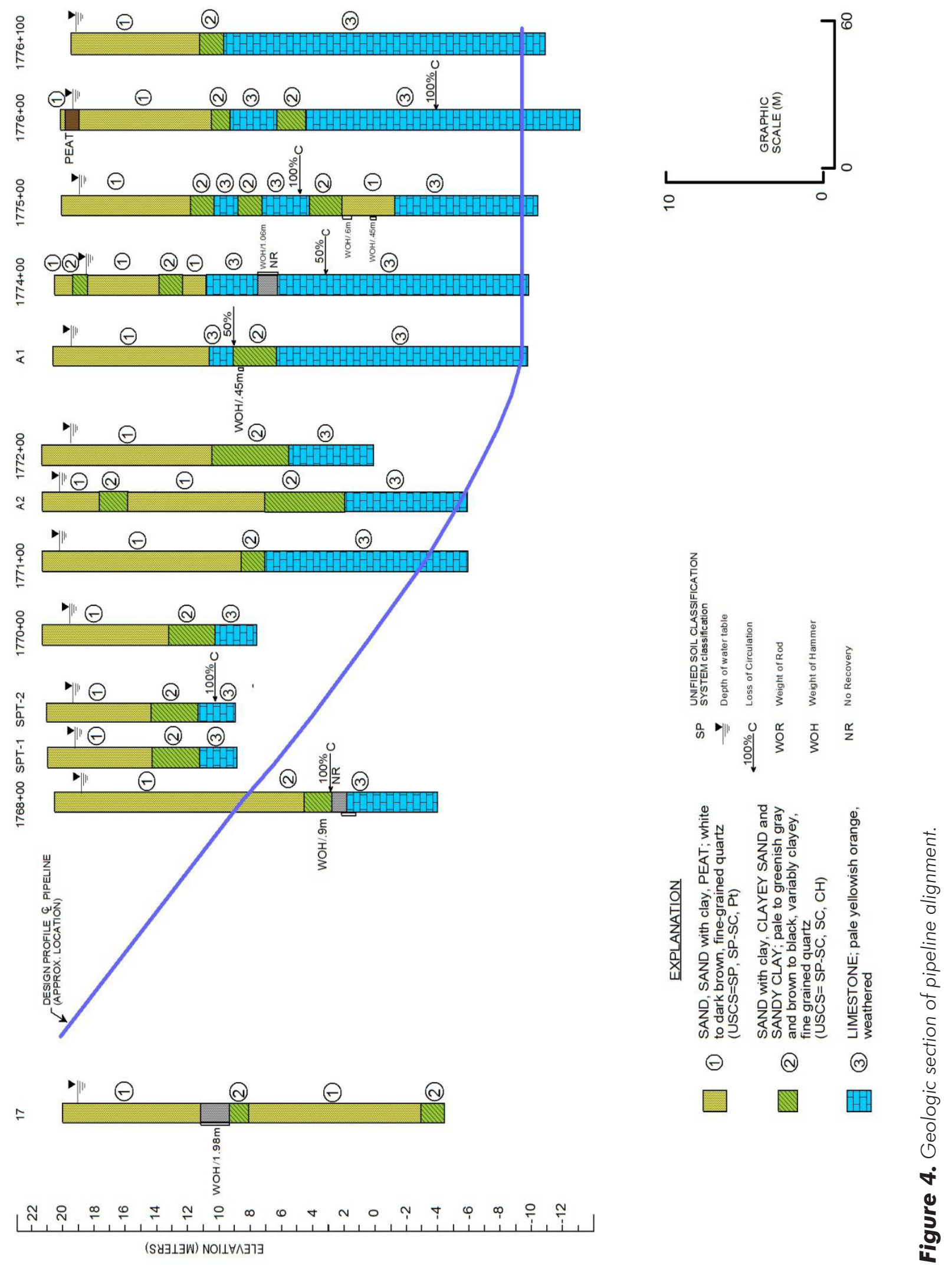
with Suwannee Limestone (Oligocene). A thin section of the Tampa Member of the Arcadia Formation (Miocene) also appears to occur in the upper portion of the limestone unit, but is difficult to differentiate from the underlying Suwannee Limestone (Arthur et al., 2008).

\section{Monitoring of Pipeline Construction}

As described, the gas pipeline was installed through a large diameter HDD borehole. HDD is a multi-stage process involving the following phases:

Pilot Hole: Initially, a small diameter pilot borehole is drilled. The borehole orientation is controlled by varying the angle of the drill bit. During drilling, the location of the borehole is surveyed using electromagnetic methods.

Reaming Process: Upon completion of the pilot hole, the borehole is enlarged. Reaming tools with increasing diameters are alternatively pushed and pulled in multiple passes through the borehole until it reaches the final diameter.

Mud Pass: After the final borehole diameter is reached, a mud pass or packer reamer is passed through the directional borehole to clean and remove soil and rock cuttings and to ensure the borehole has been filled with the drilling fluid to allow for a smooth lubricated pull back of the steel pipeline.

Pull Back: The final stage involves pulling the pipeline through the reamed borehole. A weld cap and swivel are welded to the end of the pipeline, which is then attached to the drill string to prevent rotation of the pipeline as it is pulled through the borehole. Depending on the size of the pipe, artificial buoyancy measures may be

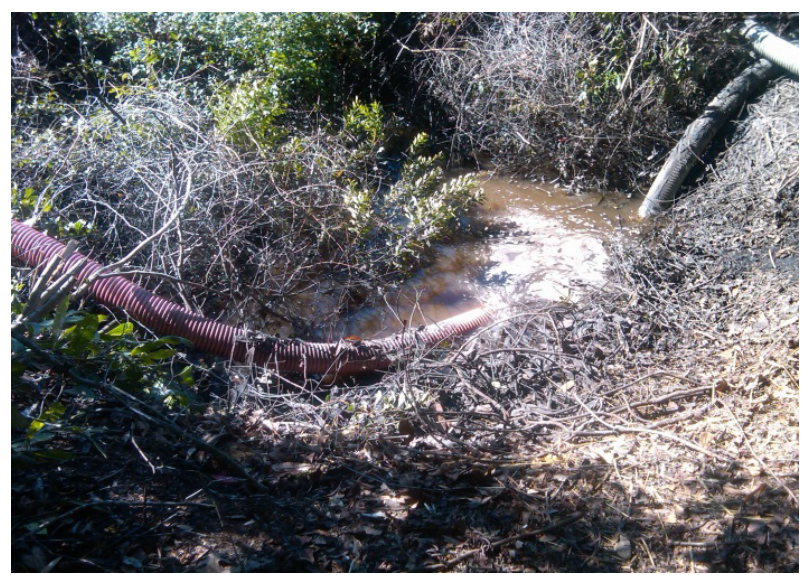

employed to maintain neutral buoyancy in the pipeline. At the subject property, a vibration or hammer device was apparently utilized to facilitate the installation of the pipeline through the borehole, resulting in noticeable ground vibrations in the area.

Monitoring of site conditions were conducted over the course of the HDD boring and installation of the pipeline. The monitoring consisted of a review of available daily drilling reports provided by the HDD drilling contractor, as well as periodic inspections of the property. Several notable events occurred during completion of the HDD boring and installation of the gas pipeline. These included the formation of several ground settlement/collapse features and associated discharges of drilling mud ("blow-outs"). These features were located within and near the pipeline easement in the northwestern portion of the site (Figure 5). Noticeable ground vibrations also occurred largely during installation of the pipeline within the borehole.

\section{Ground Vibration Monitoring}

Ground vibration monitoring was conducted during the HDD drilling and pipeline installation to address concerns regarding potential damage to building structures. Excessive ground vibrations and ground collapses had occurred at a similar HDD boring site in central Pasco County, north of the subject property.

The ground vibration monitoring utilized a remote seismograph system, which measures peak particle velocity, frequency, and air overpressures produced by vibration sources. The system records on a continuous basis in a histogram recording at a rate of 1000 samples per second with a maximum peak particle velocity

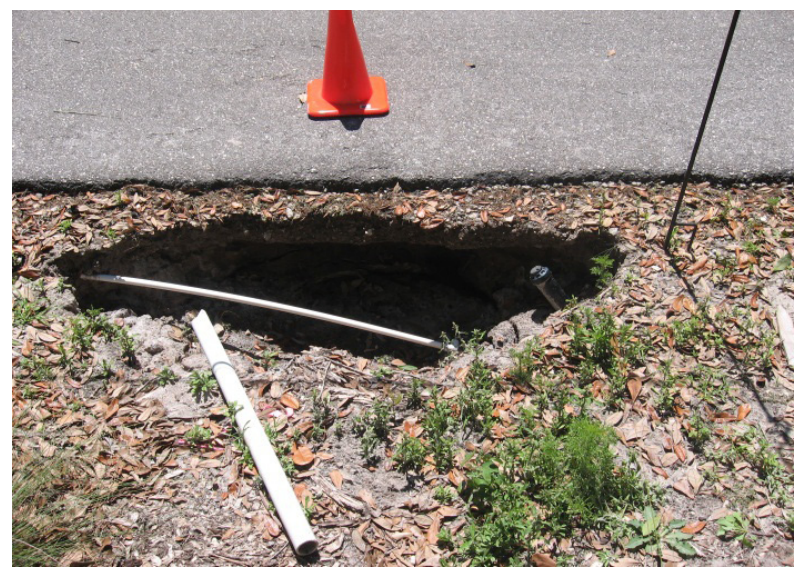

Figure 5. Photographs of "blowout" and ground collapse features. 
(PPV) recorded every minute. Data are transmitted via a cellular telemetry system. The geophone records vibrations on the longitudinal, transverse, and vertical axes. The seismograph was installed adjacent to the pipeline easement near one of the masonry outbuildings (Figure 2).

Although no specific standards have been established to evaluate ground vibrations, vibration data are often compared to U.S. Bureau of Mines (USBM) criteria for evaluating damage to building structures from blasting in mines and quarries (Siskind et al., 1980). While ground vibrations can be perceived by humans at very low levels $(\mathrm{PPV}=0.01$ to $0.1 \mathrm{in} . / \mathrm{sec}$.), vibration levels required to cause damages to building structures are much higher, ranging from $0.5 \mathrm{in}$./ $\mathrm{sec}$ at frequencies of $0.3 \mathrm{~Hz}$ to 2.0 in./sec. at $100 \mathrm{~Hz}$. At the subject property, generally low vibration levels were measured during the monitoring period. Maximum daily peak particle velocities (PPVs) ranged from 0.008 to $0.053 \mathrm{in}$./ $\mathrm{sec}$. at frequencies of 0.2 to $100 \mathrm{~Hz}$. The highest ground vibrations appeared to correlate, in part, with installation of the gas pipeline within the HDD boring, which apparently involved use of the hammering device and perceived ground vibrations. However, in each instance the measured ground vibrations were well below USBM criteria for building damage, ranging from $1 \%$ to $2 \%$ of the limits for the given frequency. However, while standards were not met, neighboring homes felt the vibrations associated with advancement of the pipe and complained of the noise created by the hammering efforts associated with installation of the pipe through the borehole.

\section{Geologic Hazards Analysis Geologic Hazards}

Based on local geologic conditions at the site, induced sinkhole activity or ground subsidence is a significant geologic hazard at the subject property. There are numerous examples of induced sinkholes related to ground water pumping in the region, including documented 1964 and 1973 sinkhole occurrences in the vicinity of the Section 21 and South Pasco well fields (Sinclair et al., 1985; Tihansky, 1999). More recently, large numbers of sinkholes developed in 1998 at a property in southwestern Hernando County during development of a large capacity water production well. In 2009 and 2010, multiple sinkholes formed in the Plant City/Dover areas (Hillsborough County) in association with heavy irrigation pumping for freeze protection of strawberry crops. These sinkholes caused substantial damages to private and public buildings and infrastructure.

Sinkhole formation in karst areas can also be triggered by construction activities such as water impoundment in reservoirs and retention basins, loading and ground vibrations from heavy equipment, changes to natural drainage patterns by diversion of stormwater, and drilling of borings and water wells. Examples of construction-related sinkholes are also common in the area. In western Pasco and Hernando counties, sinkholes have frequently formed in stormwater retention basins, typically following heavy rain events. Ground subsidence events have also been known to occur during drilling of water wells and even geotechnical borings. In addition, the authors are familiar with an occurrence of induced sinkhole activity in 2007 during construction of the Land O' Lakes water reuse reservoir. At the site, numerous collapse sinkholes formed during construction of a soilbentonite seepage cutoff wall within a dike associated with the reservoir. The sinkholes likely developed in response to the increased hydraulic loadings imposed by the soil-bentonite slurry on weakened soil zones and voids near the dissolutioned limestone bedrock surface.

\section{Induced Sinkhole Formation}

At the subject property, multiple ground settlement/ collapse features or induced sinkholes formed in response to the HDD boring and pipeline installation. The "blow-out" features ranged from approximately $4 \mathrm{ft}$. to greater than $10 \mathrm{ft}$. in diameter and were located within or near the pipeline easement in the western portion of the site (Figures 2 and 5). Drilling mud was discharged to the ground in three of the settlement/collapse features indicating a hydraulic connection with the underlying HDD boring and deeper limestone formation.

These induced sinkholes are theorized to have been triggered by increased stresses on preexisting weakened soil and rock materials associated with incipient sinkhole conditions in the subsurface. Based on the SPT borings, such conditions appear to exist as weakened or partially raveled zones within the overburden soils above the limestone bedrock, or as soil in-filled zones within dissolution conduits within the limestone bedrock. These induced sinkholes which formed in association with the previous and current pipeline construction, and 
the similar collapse events at other HDD boring sites indicate that induced sinkholes should be considered a common geologic hazard associated with HDD drilling and pipeline construction in the region.

Two mechanisms of induced sinkhole formation appear to be occurring at the site, depending on whether the HDD boring was advanced within overburden soils or in limestone. In the western portion of the site, where the HDD boring was advanced through sandy overburden soils, the large diameter borehole entailed the removal of significant amounts of soil materials, which would lead to further weakening of any incipient raveled zones intercepted by the boring. The high fluid pressures and volumes of drilling mud utilized in the drilling would cause significant erosion of the loose soils, enlarging the weak soil zones, and triggering further raveling. The larger of these weak zones eventually propagated upward to the land surface resulting in ground settlement and collapse.

In the central and eastern portions of the site, the HDD boring reached its target depth and was advanced through limestone. Soil-filled dissolution conduits are common features within the Suwannee Limestone, occurring as vertical shafts, pits, and dissolutionally-enlarged fissures that often connect with deeper cavern systems (Yon and Hendry, 1972; Wilson and Shock, 1996). Given the abundance of these features in the region and their presence in the SPT borings at the site, it is probable these structures were encountered during advancement of the HDD boring. The elevated fluid pressures and flow of the drilling mud would cause erosion of weaker zones in the soil-filled conduits, potentially loosening soil plugs near the bedrock surface and triggering raveling of the overburden soils. These conditions could also result in ground settlement or collapse if the raveling propagates close to the land surface.

In addition to the current ground settlement/collapse events at the site, there is an elevated risk of further ground subsidence associated with the HDD boring and pipeline installation. It is important to note that the induced sinkhole features that occurred in association with the HDD boring have established a hydraulic connection between the limestone, the pipeline bore, and the land surface. These connections allowed the drilling mud from the borehole to discharge to the surface during drilling operations, but may have also extended through any overburden soils below the boring and into the limestone bedrock. These weakened soil zones would remain in the subsurface and may trigger future ground settlement as the drill mud dissipates with time.

There is also a probability that additional zones of eroded and raveled soil zones are present in the subsurface that have not yet propagated to the land surface. The subsurface data from the geotechnical investigation are favorable for incipient sinkhole conditions over much of the pipeline corridor. An abrupt increase in depth to limestone bedrock along with zones of weak soils was found in SPT borings located in the northwestern portion of the site. The large wetland basin in the area appears to correspond with the underlying basin feature in the limestone, suggesting the presence of a large paleo-karst structure and associated raveled soil zones in the subsurface. To the east, deeper zones of lowstrength overburden soils and very loose and soft soil in-filled zones in the limestone were found in several borings. Collectively, these data suggest a probability that the HDD boring intercepted weak and raveled zones in the overburden and soil-filled conduits in the limestone. Depending on the degree of erosion, these weakened zones may have developed to the point to serve as potential locations of future ground settlement. In the authors' opinion, the potentially impacted areas would encompass the pipeline easement and potentially affecting building structures on the site.

\section{Acknowledgements}

We gratefully acknowledge support of the property owner who funded the investigation. The geophysical survey and ground vibration monitoring were performed by GeoView, Inc. and GeoSonics, Inc. BCI Engineering $\&$ Scientists, Inc., who employed the senior author during initial portions of the project, is also acknowledged.

\section{References}

Arthur JD, Fischler C, Kromhout C, Clayton JM, Kelley GM, Lee R, Li L, O'Sullivan, M, Green, RC, Werner, CL. 2008. Hydrogeologic Framework of the Southwest Florida Water Management District. Florida Geological Survey Bulletin No. 68.

Campbell KM. 1984. Geology of Hillsborough County. Florida Geological Survey Open File Report No. 6.

Healy HG. 1975. Terraces and Shorelines of Florida. Florida Department of Natural Resources Bureau of Geology Map Series No. 71. 
Horwitz MH, Smith TJ. 2003. Characteristics of stable and reactivated in-filled paleo-karst features in West-central, Florida. Geotechnical Special Publication No. 122. ASCE, Reston, VA.

Newton JG. 1987. Development of sinkholes resulting from man's activities in the Eastern United States. US Geological Survey Circular 968.

Scott TM. 1988. The lithostratigraphy of the Hawthorn Group (Miocene) of Florida. Florida Geological Survey Bulletin No. 59.

Scott TM. 2005. Revisions to the geomorphology of Florida focusing on the Eastern Panhandle and North-central Florida. In: Southeastern Geological Society Field Trip Guidebook 44. p. 18-36.

Sinclair WC, Stewart JW, Kuntilla RL, Gilboy AE, Miller RL. 1985. Types, features, and occurrence of sinkholes in the karst of West-central Florida. US Geological Survey Water Resources Investigation Report 85-4126.

Siskind DE, Stagg MS, Kopp JW, and Dowding CH. 1980. Structure response and damage produced by ground vibration from surface mine blasting. US Bureau of Mines Report of Investigation RI-8507.

Tihansky AB. 1999. Sinkholes, West-central Florida: In Land subsidence in the United States. US Geological Survey Circular 1182.

Wilson WL, Shock EJ. 1996. A description of quantitative methods for modeling new sinkhole frequency, size distribution, probability, and risk, based on actuarial statistical analysis of the new sinkhole data spreadsheet. Unpublished report by Subsurface Evaluations, Inc., Winter Park, Florida.

Yon JW, Hendry CW. 1972. Suwannee Limestone in Hernando and Pasco Counties, Florida: Part I. Florida Bureau of Geology Bulletin No. 54. 